\title{
Treatment with gamithromycin in foals with pneumonia: comparative efficacy and adverse effects of i.m. versus i.v. administration
}

\author{
Franziska Hildebrand', Steeve Giguère ${ }^{2}$ and Monica Venner ${ }^{3}$ \\ 1 University of Veterinary Medicine Hanover, Clinic for Horses, Hanover, Germany \\ ${ }^{2}$ College of Veterinary Medicine, University of Georgia, Athens, GA, USA \\ ${ }^{3}$ Equine Clinic Destedt, Destedt, Germany
}

\begin{abstract}
Summary: The aim of this study was to compare the frequency of adverse reactions and efficacy of i.v. administration of gamithromycin compared to i.m. gamithromycin for the treatment of foal bronchopneumonia on a farm endemic for infections caused by Rhodococcus equi. 60 foals with bronchopneumonia and treated with gamithromycin were retrospectively divided into two treatment groups. In the foals of group $1(\mathrm{n}=40)$ gamithromycin $\left(6 \mathrm{mg} / \mathrm{kg}\right.$ body weight, Zactran ${ }^{\circledR}$, Merial) was injected once weekly for six weeks in the semitendinosus or the semimembranosus muscle. In the foals of group $2(\mathrm{n}=20)$ gamithromycin $\left(6 \mathrm{mg} / \mathrm{kg}\right.$ body weight, Zactran $\left.{ }^{\circledR}\right)$ was injected intravenously once weekly for six weeks in the jugular veins. The animals in group 2 were also treated with rifampin (10 mg/ $/ \mathrm{kg}, \mathrm{q} 24 \mathrm{~h}, \mathrm{p} .0$.). Local and systemic adverse effects were evaluated daily in all foals. Foals whose pneumonia worsened were removed from the study. In the group of foals treated with gamithromycin i.m. 38 of $40(95 \%)$ recovered without the need to be removed from the study compared to 16 of the $20(80 \%)$ foals treated with gamithromycin i.v.. The frequency of adverse drug reactions differed significantly between administration routes. In the group of foals treated with Zactran ${ }^{\circledR}$ i.m. 23 of 40 foals (58\%) showed adverse effects. 18 foals (45\%) showed signs of colic that required treatment with analgesics, and 14 (35\%) developed a marked lameness on the side of the i.m. injection. In the group of the foals who got the Zactran ${ }^{\circledR}$ i.v. no adverse effects were observed. From these results, it can be concluded that i.v. administration of Zactran ${ }^{\circledR}$ induces significantly fewer adverse effects than i.m. administration. However, additional studies will be necessary to determine the optimal dose and dosing interval for i.v. gamithromycin that will result in similar efficacy as that achieved after i.m. administration.
\end{abstract}

Keywords: pneumonia / foal / Rhodococcus equi / macrolide / Gamithromycin / adverse effects

Citation: Hildebrand F., Giguère S., Venner M. (2015) Treatment with gamithromycin in foals with pneumonia: comparative efficacy and adverse effects of i.m. versus i.v. administration. Pferdeheilkunde 31, 165-170

Correspondence: Monica Venner PD Dr. PhD, Equine Clinic, Trift 4, 38162 Destedt, Germany, E-Mail: mvenner@gmx.de

\section{Introduction}

Respiratory infections are among the most common disorders in the growing foal. A common cause is the Gram positive facultative intracellular bacterium Rhodococcus equi ( $R$. equi), which induces chronic bronchopneumonia with abscess formation (Zink et al. 1986, Giguere and Prescott 1997, Muscatello 2012). The typical age at onset of the clinical disease is one to six months (Giguere and Prescott 1997). R. equi can cause sporadic disease, though it is more often associated with a high morbidity of $20-40 \%$ in endemically affected studs (Chaffin et al. 2003). To minimize foal losses at those breeding farms, a screening program promoting early detection of pneumonia in the growing foal is recommended (Cohen et al. 2000, Venner et al. 2012). This includes frequent clinical examinations, determination of white blood cell counts and an ultrasonographic examination of the lungs (Giguere et al. 2003, Slovis et al. 2005, McCracken and Slovis 2009). Although controlled studies are lacking, observational studies suggest that mortality can be almost abolished when disease is detected early and treated adequately (Venner et al. 2012).

Choosing an appropriate chemotherapy for the treatment of the R. equi pneumonia is crucial. Many antibiotics that are active in vitro prove to be ineffective in affected foals (Prescott and Sweeney 1985, Ainsworth 1999). Rifampin and macrolides are sufficiently lipophilic to penetrate abscesses and reach high concentrations intracellularly. The treatment of choice for R. equi pneumonia is therefore rifampin in combination with a macrolide antibiotic (Giguere et al. 2011).

Gamithromycin is a new azalide antibiotic, a subclass of macrolides, and is licenced in many countries including Germany for the treatment of BRD (Bovine Respiratory Disease) as a preparation for subcutaneous injection (Zactran ${ }^{\circledR}$ ). Gamithromycin accumulates in the pulmonary ephithelial lining fluid and the alveolar cells of foals and its concentration in these compartments exceeds the MIC90 for R. equi for approximately 7 days after a single i.m. injection at a dosage of $6 \mathrm{mg} / \mathrm{kg}$ body weight (Berghaus et al. 2012). In contrast, azithromycin in combination with rifampin, the gold standard in the treatment of the R. equi pneumonia, must be administered at least once daily due to their pharmacokinetic properties (Jack et al. 2001). The prolonged antibacterial effects of gamithromycin after a single dose could simplify the treatment regimen of $R$. equi pneumonia and reduce associated costs.

In a recent study, gamithromycin $(6 \mathrm{mg} / \mathrm{kg}$ body weight, i.m., once a week) proved to be as effective as the gold standard for the treatment of R. equi pneumonia in foals (Hildebrand et al. 2015). However, i.m. injection of Zactran ${ }^{\circledR}$ in the semitendinosus or the semimembranous muscle induced clinically relevant adverse effects such as colic and lameness (Hildeb- 
rand et al. 2015). In contrast, i.v. injection of Zactran ${ }^{\circledR}$ administered to chicken (Watteyn et al. 2013) and pigs (Wyns et al. 2014) did not result in adverse drug reactions.

The aim of the present study was to determine whether i.v. administration of gamithromycin results in a lower frequency of adverse effects compared to i.m. injections. A secondary objective was to compare the efficacy of i.v. gamithromycin to that of i.m. gamithromycin.

\section{Materials and methods}

Subjects

The present study is a retrospective observation, which was conducted on a Warmblood horse breeding farm in Germany during the breeding season 2013. R. equi pneumonia has been affecting foals on this farm for many years. R. equi has been isolated repeatedly over the last years in tracheobronchial secretions obtained from foals with pulmonary abscesses detected by ultrasonography (Venner et al. 2007b, Kilian 2008, Laemmer 2010). Furthermore, R. equi was cultured from all pulmonary lesions during post-mortem examination in 24 foals with sonographical evidence of pneumonia (Weimar 2006).

\section{Examination of the foals}

Once a week from birth to weaning, each foal was subjected to a clinical examination. This included measurement of rectal temperature, evaluation of nasal discharge (serous, mucous, purulent) and assessment of the mandibular lymph nodes. In addition, auscultation of the trachea and lungs was performed. Furthermore, white blood cells were counted. Each parameter was assessed using a scoring system. The addition of all individual values resulted in the so-called "clinical score" (Ohnesorge et al. 1998, Venner et al. 2007a, 2009).

Foals with a temperature $>39.5^{\circ} \mathrm{C}$, abnormal auscultation of the lungs and trachea, dyspnea, coughing, purulent nasal discharge or a white blood cell count above 13,000 cells/ $\mu$ l, were examined using thoracic ultrasonography. For this purpose, a portable battery-powered ultrasonography unit (Tringa Linear, Esaote Piemedical, Netherlands) with a $7.5 \mathrm{MHz}$ linear transducer was used. To ensure a good transmission, the hair coat in the area of the lung field was sprayed with isopropyl alcohol. The entire lung field from the third to the 15 th intercostal space on both sides of the thorax was exami- ned. For the purpose of this study, hypoechoic areas of consolidation of at least $1 \mathrm{~cm}$ were defined as an "abscesses". The addition of the diameter of all abscesses (in $\mathrm{cm}$ ) of both lung sides then formed the so-called "abscess score", which was used as an indicator for the severity of pulmonary lesions.

\section{Inclusion criteria and treatment protocols}

For inclusion in the study, foals had to be at least four weeks of age and present an abscess score between 3 to $23 \mathrm{~cm}$. Foals with white blood cell counts $>25,000$ cells $/ \mu$ l or dyspnea were excluded.

The foals were treated for a minimum of 4 weeks with gamithromycin (Zactran ${ }^{\circledR}, 150 \mathrm{mg} / \mathrm{ml}$, Merial, Lyon, France) at a dose of $6 \mathrm{mg} / \mathrm{kg}$ body weight (Zactran ${ }^{\circledR} 1 \mathrm{ml} / 25 \mathrm{~kg}$ body weight) once a week using two different routes of administration. In the animals of group 1 Zactran ${ }^{\circledR}$ was administered as a monotherapy and injected in the semimembranosus or semitendinosus muscles. The injections were performed weekly alternating left and right hind limbs. In the foals of group 2 , Zactran ${ }^{\circledR}$ was administered by i.v. injection into the jugular vein via a catheter $(18 \mathrm{G}, 1.3 \times 45 \mathrm{~mm}$, B. Braun Melsungen AG, Melsungen, Germany) in combination with rifampin (600mg Rifa ${ }^{\circledR}$, Grünenthal GmbH, Aachen, Germany), which was administered at a dose of $10 \mathrm{mg} / \mathrm{kg}$ body weight once daily p.o.. The injections were performed weekly alternating left and right jugular veins. To accurately determine the dose of each drug, the body weight of the foal was measure before each injection using a tape (Pony Measuring Tape, Boehringer Ingelheim, Ingelheim am Rhein) and at regular intervals with a scale (Mobile Pferdewaage, Jagstzell Fa., Germany). In addition, all foals in both groups were given acetylcysteine (Equimucin ${ }^{\circledR}, \mathrm{cp}$-Pharma, Burgdorf, Germany) at a dose of $10 \mathrm{mg} / \mathrm{kg}$ body weight p.o. twice daily throughout the treatment period.

After inclusion in the study, all foals were further examined weekly as described above. Ultrasonography of the lungs was performed one week after the beginning of therapy and at the planed end of treatment ( 4 to 6 weeks after beginning of treatment) to evaluate treatment success. Furthermore, each foal was examined several times by a veterinarian on the day of injection and daily for the next four days post-injection for adverse drug reactions such as swelling of the injection site and phlebitis, colic, or lameness.

If the foal's condition worsened during the study period with an abscess score rising to a total of $\geq 23 \mathrm{~cm}$ or if a clinical

\begin{tabular}{lccc}
\hline Table 1 & \multicolumn{1}{c}{ Baseline parameters at the time of initiation of therapy with gamithromycin i.m. or i.v. } & & \\
\hline Variables & GAM i.m. (=40) & GAM i.v. (n=20) & P value \\
\hline Males (\%) & $20(50.0)$ & $11(55.0)$ & 0.788 \\
Females (\%) & $20(50.0)$ & $2(45.5)$ & 0.788 \\
Clinical score & $2(1-4)^{A}$ & $11.0(4.1-16.0)$ & 0.129 \\
Abscess score (cm) & $10.0(8.0-16.0)$ & $6(2-12)$ & 0.694 \\
Number of abscesses & $7(3-11)$ & $12.8(6.9-23.3)$ & 0.517 \\
WBC $\left(\times 10^{9} /\right.$ l) & $14.2(10.0-20.4)$ & $125(75-211)$ & 0.351 \\
Age at diagnosis (days) & $120(73-161)$ & 0.784 \\
\hline
\end{tabular}

\footnotetext{
${ }^{A}$ Median $\left(10^{\text {th }}\right.$ and $90^{\text {th }}$ percentiles).
} 
deterioration such as dyspnea or a febrile phase occurred, the foal was withdrawn from the study and therapy was changed to azithromycin (Zithromax ${ }^{\circledR}$ film-coated tablets, Pfizer, Karlsruhe, Germany) in combination with rifampin (600 mgRifa ${ }^{\circledR}$, Grünenthal $\mathrm{GmbH}$, Aachen) once daily at a dose of $10 \mathrm{mg} / \mathrm{kg}$ body weight p.o..

As during the study adverse effects occurred, the decision was made to evaluate eight foals, that had been administered Zactran ${ }^{\circledR}$ i.m., at the age of 6 month to assess ultrasonographical changes of the semitendinosus or semimembranosus muscles.

\section{Data collection}

At the time of diagnosis, one week and six weeks later rectal body temperature, clinical score and white blood cell count, number of pulmonary abscesses and "abscess score" were recorded (Tab. 1). A comparison of this data allowed comparison of the homogeneity and severity of disease in both groups. Furthermore, duration of treatment, occurrence of adverse drug reactions and finally the number of foals that had to be removed from the study were evaluated.

\section{Data analysis}

Normality of the data and equality of variances were assessed using Shapiro-Wilk's and Levene's tests, respectively. Comparison of baseline and outcome variables between treatment groups was done using a Mann Whitney $U$ test. Comparisons between proportions (e.g. sex, proportion of foals that recovered without a change in therapy, proportion of foals with adverse effects) were done using Fisher's exact test. Possible association between development of colic and lameness was explored using the McNemar test for paired proportion. A two-way ANOVA with repeated measures was used to evaluate the effect of treatment group, time, and the interactions between treatment group and time on the number of abscesses and abscess score of foals that responded to the initial treatment. Data that did not meet assumptions for parametric testing were transformed to ranks prior to analysis. When indicated, multiple pairwise comparisons were done using the Holm-Sidak method. For all analyses, $\mathrm{P}<0.05$ was considered significant.

\section{Results}

Adverse effects were not noted during or after i.v. administration of Zactran ${ }^{\circledR}$. Overall, 23 of 40 foals (58\%) in the Zac-
$\operatorname{tran}^{\circledR}$ i.m. treatment group displayed signs of adverse reactions to the drug whereas adverse reactions were not noted during or after administration of Zactran ${ }^{\circledR}$ i.v. $(P<0.001)$. Adverse effects consisted of signs of colic ( $n=18 ; 45 \%)$ immediately after injection and lameness of the hind limb that was injected $(n=14 ; 35 \%)$. Signs of colic were mild in most foals and consisted of lying down and flank watching. Most episodes of colic were after the first and second injection of Zactran ${ }^{\circledR}$. Four foals had severe episodes of colic after each injection. These foals were treated with metamizol (Metapyrin ${ }^{\circledR}, 500 \mathrm{mg} / \mathrm{ml}$, Serumwerk Bernburg AG, Bernburg) at a dose of $50 \mathrm{mg} / \mathrm{kg}$ body weight during the episodes. In 12 foals, lameness was grade IV/N on the AAEP lameness scale the day after the first or and second injection and resolved progressively over the next $72 \mathrm{~h}$. In six foals, lameness was grade $\mathrm{V} / \mathrm{V}$ the day after each injection and resolved progressively over the next $72 \mathrm{~h}$. The association between development of lameness and signs of colic was not statistically significant $(P=0.424)$ (Tab. 2).

Subsequently performed ultrasonographic examinations of the semitendinosus and semimembranosus muscle of eight foals showed marked focal hyperechogenicity of muscle structure, which were also still visible in six out of eight foals on both hind limbs several months after treatment (Figure 1).

For the comparison of the efficacy of both routes of administration of gamithromycin in the treatment of pneumonia in foals, the baseline parameters at the time of initiating therapy were not significantly different between treatment groups
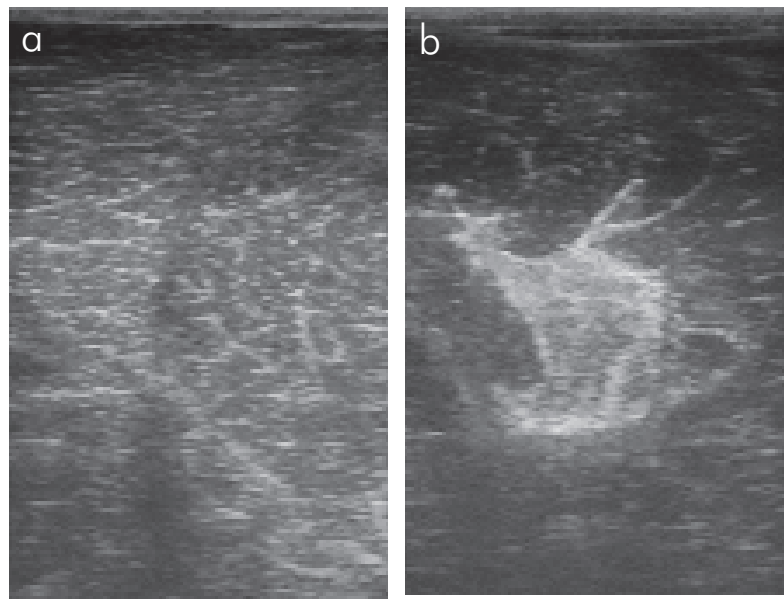

Fig 1 a: Ultrasonographic image of the normal semimembranosus, semitendinosus muscles of a 6 month old foal. b: Ultrasonographic image of a focal densification in the semitendinosus muscles of a 6 months old foal, 3 months after repeated i.m. administrations of Zactran $^{\circledR}$ (three injections at 14 days interval).

\begin{tabular}{|c|c|c|c|}
\hline Variables & GAM i.m. $(n=40)$ & GAM i.v. $(n=20)$ & $P$ value \\
\hline Recovered without change in antimicrobial therapy (\%) & $38(95.0)$ & $16(80.0)$ & 0.089 \\
\hline $\begin{array}{l}\text { Duration of therapy in foals that responded without } \\
\text { change in antimicrobial (days) }\end{array}$ & $45(40-54)^{A}$ & $44(28-48)^{A}$ & 0.167 \\
\hline Lameness (\%) & $14(35)$ & $0(0)$ & 0.002 \\
\hline Colic (\%) & $18(45)$ & $0(0)$ & $<0.001$ \\
\hline Total adverse effects (\%) & $23(58)$ & $0(0)$ & $<0.001$ \\
\hline
\end{tabular}

${ }^{A}$ Median $\left(10^{\text {th }}\right.$ and $90^{\text {th }}$ percentiles) 
(Table 1). There was tendency $(P=0.089)$ for a higher proportion of foals that recovered without the need for a change in therapy in foals treated with gamithromycin i.m. (38/40 or $95 \%)$ compared to foals treated with gamithromycin i.v. (16/20 or $80 \%)$. The duration of the initial therapy was not significantly different between groups (Table 2). There were significant interactions between treatment group and time for the number of abscesses $(P=0.028)$ and abscess score $(P=0.003)$. Number and abscess score were significantly lower at six weeks than at baseline (time 0) for both treatment groups (Figure 2). After one week of therapy, number of abscesses and abscess score were significantly lower in foals treated with gamithromycin i.m. compared to foals treated with gamithromycin i.v.
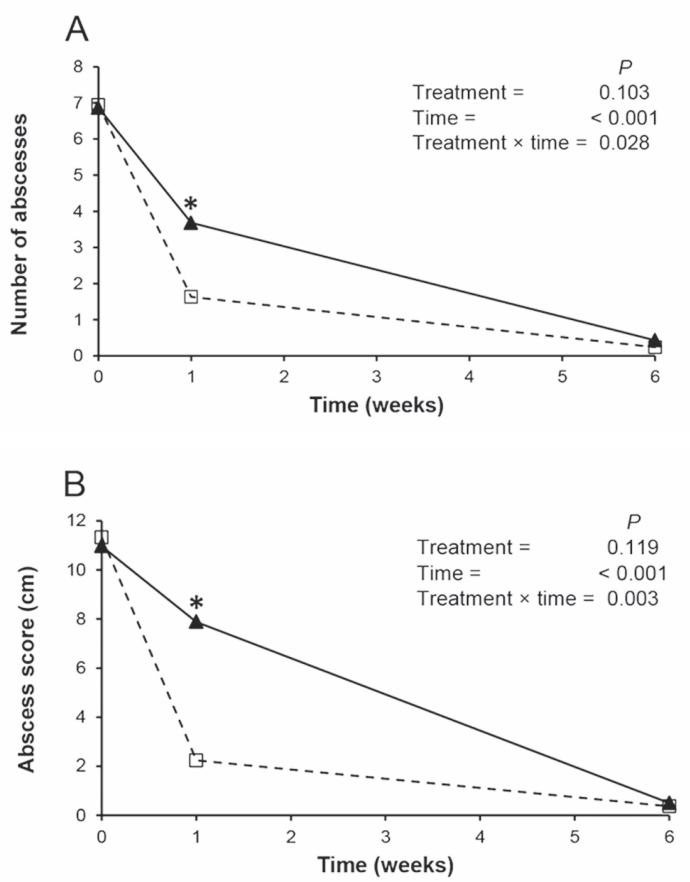

Fig 2 Least square mean number of abscesses (A) and abscess scores (B) at baseline (time 0 ) and after 1 and 6 weeks of treatment in foals that responded to therapy with gamithromycin IM $(n=38)$ or IV $(n=16)$. *Indicates a significant difference between foals treated with gamithromycin IM vs IV at a given time point $(P<0.05)$. $-.-=I M,-=I V$

\section{Discussion}

The high frequency of adverse drug reactions after i.m. administration of Zactran ${ }^{\circledR}$, will likely limit administration by this route to foals. Although discomfort and swelling at the injection site after subcutaneous injection of Zactran ${ }^{\circledR}$ in cattle is a known adverse effect (Zactran ${ }^{\circledR}$ Merial, package insert), the pain reaction noted in many foals after i.m. injection was much more severe than what has been reported in cattle. In another study in which Zactran ${ }^{\circledR}$ was also administered as an i.m injection, no such adverse effects were observed (Berghaus et al. 2012), but this study was only performed in six foals receiving a single injection between 4 and 8 weeks of age

The observed transient lameness could be a result of inadequate injection technique. However, injections were performed by four different veterinarians and the occurrence of lameness was evenly distributed. The lameness is therefore more likely due to the irritating effect of Zactran ${ }^{\circledR}$ than to inadequate injection techniques. A possible reason for the irritating nature of Zactran ${ }^{\circledR}$ is the fact that the drug is highly hyperosmolar (Personal communication, Institute of Pharmacy, Ernst-Moritz-Arndt-University Greifswald).

Another known adverse effect of treatment with macrolides and azalides is enterocolitis (Stratton Phelps et al. 2000, Giguere et al. 2004). This was not observed in the present study. The signs of abdominal discomfort were mild to severe and seen almost immediately after the injection. Therefore, the signs of colic were more likely associated to pain due to i.m. injection rather than to enterocolitis.

In contrast to i.m. injection, i.v. administration of Zactran ${ }^{\circledR}$ was not associated with adverse effects. Thus i.v. administration via an i.v. catheter seems to be a safe alternative. Given the irritating nature of the drug, perivenous injections should be avoided. However, studies evaluating the pharmacokinetics of the drug after i.v. administration to foals will be necessary. In cattle, Zactran ${ }^{\circledR}$ is administered as a subcutaneous injection. Our unpublished observation in foals is, that subcutaneous Zactran ${ }^{\circledR}$ leads to considerable local pain reactions that lasted for approximately five days. Therefore, the subcutaneous route of administration of Zactran ${ }^{\circledR}$ can not be recommended in foals. Consequently, the i.v. administration was chosen in our study, the authors being well aware that it is not specified by the manufacturer, but well tolerated in chicken (Watteyn et al. 2013) and pig (Wyns et al. 2014).

In conclusion, it can be stated that Zactran ${ }^{\circledR}$ is very well tolerated by foals if given intravenously through a catheter placed in a jugular vein. However, additional studies will be necessary to determine the optimal dose and dosing interval that will result in similar efficacy as that achieved after i.m. administration.

The synergistic action of macrolides administered in combination with rifampin has been proven both in vitro and in vivo (Prescott and Nicholsen 1984, Nordmann and Ronco 1992). However, a recent study showed that monotherapy with gamithromycin is as effective in the treatment of pneumonia in foals as therapy with the gold standard rifampin in combination with azithromycin (Hildebrand et al. 2015). The present results showed a tendency toward monotherapy with gamithromycin administered i.m. being more effective than gamithromycin injected i.v. in combination with rifampin. In addition, after 1 week of therapy, number of abscesses and abscess score were significantly lower in foals treated with gamithromycin i.m. compared to foals treated with gamithromycin i.v. Therefore, the combination treatment (rifampin/gamithromycin i.v.) appears less effective than the monotherapy gamithromycin i.m.. Differences in the pharmacokinetic profile of gamithromycin i.m. versus i.v. might explain differences in efficacies. The pharmacokinetics of gamithromycin after i.v. administration has not been investigated in foals. It is possible that a higher dosage, shorter dosing interval, or both are required. Alternatively, the apparent lower efficacy of gamithromycin i.v. might be due to the fact that rifampin interacts with the metabolism of many coadministered drugs (Aktories et al. 2005). This has been shown to occur in foals, where rifampin influences the pharmacokinetics of clarithromycin (Peters et al. 2011 , 
2012, Spiekermann 2014). The concentrations of clarithromycin in serum and in alveolar cells are reduced by more than $90 \%$ when administered with rifampin compared to monotherapy (Peters et al. 2011 ). Whether rifampin has a similar effect on the concentrations of gamithromycin in blood and alveolar cells has not been investigated. Additional studies will be required to identify the reasons for the apparent lower efficacy of gamithromycin i.v. in combination with rifampin compared to gamithromycin i.m. in monotherapy.

\section{Conflict of interest statement}

The authors exclude any conflict of interest regarding technical devices of drugs used in that study.

\section{References}

Ainsworth D. M. (1999) Rhodococcal infections in foals. In: Equine Vet. Educ. 11, 191-198

Aktories K., Förstermann U., Hofmann F., Starke K. (Hg.) (2005) Allgemeine und spezielle Pharmakologie und Toxikologie. 9. Aufl. Elsevier München

Berghaus L. J., Giguere S., Sturgill T. L., Bade D., Malinsky T. J., Huang R. (2012) Plasma pharmacokinetics, pulmonary distribution, and in vitro activity of gamithromycin in foals. In: J. Vet. Pharmacol. Therap. 35, 59-66

Berghaus L. J., Giguere S., Guldbech K. (2013) Mutant prevention concentration and mutant selection window for 10 antimicrobial agents against Rhodococcus equi. Vet. Microbiol. 166, 670-675

Burton A. J., Giguere S., Sturgill T. L., Berghaus L. J., Slovis N. M., Whitman J. L., Levering C., Kuskie K. R., Cohen N. D. (2013) Macrolide- and Rifampin-Resistant Rhodococcus equi on a horse breeding farm, Kentucky, USA. Emerg. Infect. Dis. 19, 282-285

Chaffin K. M., Cohen N. D., Martens R. J., Edwards R. F., Nevill M. (2003) Foal-related risk factors associated with development of Rhodococcus equi pneumonia on farms with endemic infection. J. Am. Vet. Med. Assoc. 223, 1791-1799

Cohen N. D., Chaffin M. K., Martens R. J. (2000) Control and Prevention of Rhodococcus equi Pneumonia in foals. Comp. Cont. Educ. Pract. Vet. 22, 1062-1071

Giguere S., Prescott J. F. (1997) Clinical manifestations, diagnosis, treatment and prevention of Rhodococcus equi infections in foals. Vet. Microbiol. 56, 313-334

Giguere S., Cohen N. D., Chaffin M. K., Slovis N. M., Hondalus M. K., Hines S. A., Prescott J. F. (2011) Diagnosis, Treatment, Control, and Prevention of Infections Caused by Rhodococcus equi in Foals. J. Vet. Intern. Med. 25, 1209-1220

Giguere S., Hernandez J., Gaskin J., Miller C., Bowman J. L. (2003) Evaluation of white blood cell concentration, plasma fibrinogen concentration and an agar gel immunodiffusion test for early identification of foals with Rhodococcus equi pneumonia. J. Am. Vet. Med. Assoc. 222, 775-781

Giguere S., Jacks S., Roberts G. D., Hernandez J., Long M. T., Ellis C. (2004) Retrospective comparison of azithromycin, clarithromycin, and erythromycin for the treatment of foals with Rhodococcus equi pneumonia. J. Vet. Intern. Med. 18, 568-573

Giguere S., Lee E., Williams E., Cohen N., Chaffin M. K., Halbert N., Martens R. J., Franklin R. P., Clark C. C., Slovis N. M. (2010) Determination of the prevalence of antimicrobial resistance to macrolide antimicrobials or rifampin in Rhodococcus equi isolates and treatment outcome in foals infected with antimicrobial-resistant isolates of $R$ equi. In: J. Am. Vet. Med. Assoc. 237, 74-81

Giguere S., Lee E. A., Guldbech K. M., Berghaus L. J. (2012) In vitro synergy, pharmacodynamics, and postantibiotic effect of 11 antimicrobial agents against Rhodococcus equi. Vet. Microbiol. 160, 207-213
Hildebrand F., Venner M., Giguere S. (2015) Evaluation of the efficacy of gamithromycin for the treatment of foals with mild to moderate bronchopneumonia. J. Vet. Intern. Med. 29, 333-338

Jacks S., Giguere S., Gronwall R.R., Brown M.P., Merritt K. A. (2001) Pharmacokinetics of azithromycin and concentration in body fluids and bronchoalveolar cells in foals. In: Am. J. Vet. Res. $62,1870-1875$

Kilian K. (2008) Vergleichende Untersuchungen zum Nachweis von Rhodokokkus equi in der Atemluft, im Treacheobronchialsekret und im Kot von Fohlen. Diss. Med. Vet. Hannover

Lämmer M. (2010): Nachweis von Rhodococcus equi in Kot und Trachealsekret bei Fohlen: Vergleichende Untersuchung zwischen gesunden Fohlen und Fohlen mit Lungenabszessen. Diss. Med. Vet. Hannover

McCracken J. L., Slovis N. M. (2009) Use of thoracic ultrasound for the prevention of Rhodococcus equi pnumonia on endemic farms. Proc. Am. Assoc. Equine Pract. 55, 38-44

Muscatello G. (2012) Rhodococcus equi pneumonia in the foal part 1: pathogenesis and epidemiology. Vet. J. 192, 20-26. DOI: 10.1016/i.tvil.2011.08.014

Nordmann P., Ronco E. (1992) In-vitro antimicrobial susceptibility of Rhodococcus equi 29, 383-393

Ohnesorge B., Trötschel C., Deegen E. (1998) Bestimmung von Totraum und expiratorischem Mischvolumenverhältnis zur Diagnostik chronischer Lungenerkrankungen. Pferdeheilkunde 14, 450-455

Peters J., Block W., Ooswald S., Freyer J., Grube M., Kroemer H.K., Lämmer M., Lütjohann D., Venner M., Siegmund W. (2011) Oral absorption of clarithromycin is nearly abolished by chronic comedication of rifampicin in foals. Drug Metab. Dispos. 39, 1643-1649

Peters J., Eggers K., Oswald S., Block W., Lütjohann D. , Lämmer M., Vnner M., Siegmund W. (2012) Clarithromycin is absorbed by an intestinal uptake mechanism that is sensitive to major inhibition by rifampicin: results of a short-term drug interaction study in foals. Drug Metab. Dispos. 40, 522-528. DOI: 10.1124/dmd.111. 042267

Prescott J. F., Nicholsen V. M. (1984) The effects of combinations of selected antibiotics on the growth of Corynebacterium equi. J. Vet. Pharmacol. Therap. 7, 61-64

Prescott J. F., Sweeney C. R. (1985) Treatment of Corynebacterium equi pneumonia of foals: a review. J. Am. Vet. Med. Assoc. 187, 725-728

Slovis N. M., McCracken J. L., Mundy G. (2005) How to use thoracic ultrasound to screen foals for Rhodococcus equi at affected farms. Proc. Am. Assoc. Equine Pract. 51, 274-278

Spieckermann L. (2014) Einfluss von Rifampicin auf die Pharmakokinetik und pulmonale Verteilung von Clarithromycin nach simultaner und verzögerter Verabreichung bei gesunden Fohlen. Diss. Med. Vet. Hannover

Stratton-Phelps M., Wilson W. D., Gardener I. A. (2000) Risk of adverse effects in pneumonic foals treated with erythromycin versus other antibiotics: 43 cases (1986-1996). J. Am. Vet. Med. Assoc. 217, 68-73

Venner M., Kerth R., Klug E. (2007a) Evaluation of tulathromycin in the treatment of pulmonary abscesses in foals. Vet. J. 174, 418-421

Venner M., Meyer-Hamme B., Verspohl J., Hatori F., Shimizu N., Sasaki Y., Kakuda T., Tsubaki S, Takai S. (2007b) Genotypic characterization of VapA positive Rhodococcus equi in foals with pulmonary affection and their soil environment on a warmblood horse breeding farm in Germany. Res. Vet. Sci. 83, 311-317

Venner M., Reinhold B., Beyerbach M., Feige K. (2009) Efficacy of azithromycin in preventing pulmonary abscesses in foals. Vet. J. $179,301-303$

Venner M., Rödiger A., Lämmer M., Giguere S. (2012) Failure of antimicrobial therapy to accelerate spontaneous healing of subclinical pulmonary abscesses on a farm with endemic infections caused by Rhodococcus equi. Vet. J. 192, 293-298. DOI: 10.1016/i.tvil.201 1.07.004

Watteyn A., Plessers E., Wyns H., De Baere S., De Backer P., Croubels S. (2013) Pharmacokinetics of gamithromycin after intravenous and subcutaneous administration in broiler chickens. Poult. Sci. 92, 1516-1522 
Weimar B. M. (2006) Lungenabszesse bei Fohlen: Klinische, sonographische, endoskopischen, pathomorphologische und mikrobiologische Befunde. Diss. Med. Vet. Hannover

Wyns H., Meyer E., Plessers E., Watteyn A., De Baere S., De Backer P., Croubels S. (2014) Pharmacokinetics of gamithromycin after intravenous and subcutaneous administration in pigs. Res. Vet. Sci. 96, 160-163

Zink M. C., Yager J. A., Smart N. L. (1986) Corynebacterium equi Infections in horses, 1958-1984: a review of 131 cases. Can. J. Vet. Res. 27, 213-217

Erweiterte Zusammenfassung

\section{Unerwünschte Arzneimittelwirkungen bei der Verabrei- chung von Gamithromycin zur Behandlung von Pneu- monie bei Fohlen: Vergleich der i.m.- und i.v.-Gabe}

Infektionen der Atemwege zählen zu den häufigsten Erkrankungen in der Fohlenaufzucht. Das fakultativ intrazellulär lebende Bakterium Rhodococcus equi (R. equi) als Auslöser einer chronisch abszedierenden Bronchopneumonie ist dafür eine Hauptursache. R. equi kann sporadische Erkrankungen verursachen, führt aber besonders in endemisch betroffen Gestüten zu einer hohen Morbidität und Mortalität und hat somit einen hohen wirtschaftlichen Einfluss auf die Pferdeindustrie.

Die Auswahl eines geeigneten Chemotherapeutikums zur Behandlung der Rhodokokkose ist stark begrenzt. Lediglich Rifampicin und Makrolide weisen eine ausreichend hohe Lipophilie auf, um in die abszedierend eingeschmolzenen Lungenbereiche eindringen und den intrazellulären Erreger abtöten zu können. Die Therapie der Wahl zur Behandlung der R. equi-Pneumonie ist daher Rifampicin in Kombination mit einem Makrolidantibiotikum. Rifampicin in Kombination mit Azithromycin ist der Goldstandard in der Therapie der Rhodokokkose des Fohlens und muss aufgrund seiner pharmakokinetischen Eigenschaften mindestens einmal töglich verabreicht werden.

Gamithromycin ist ein neves Azalid-Antibiotikum, eine Untergruppe der Makrolide, und ist zur Behandlung der multifaktoriellen BRD (Bovine Respiratory Disease) in Deutschland als Präparat zur subcutanen Injektion (Zactran ${ }^{\circledR}$, Injektionslösung $150 \mathrm{mg} / \mathrm{ml}$, Merial, Lyon, Frankreich) zu gelassen. Auch beim Fohlen reichert sich Gamithromycin in der Pulmonary ephithelial lining fluid und den Lungenphagozyten an und erreicht bei einer einmaligen intramuskulären Injektion in einer Dosierung von $6 \mathrm{mg} / \mathrm{kg}$ Körpergewicht (KGW) in den Alveolarzellen eine Konzentration, die die MHK90 für R. equi 7 Tage lang überschreitet. Die Tatsache also, dass Gamithromycin bei einmaliger Applikation eine solch lang anhaltende antibakterielle Wirkung aufweist, könnte das Behandlungsregime der R. equi-Pneumonie vereinfachen und dessen Kosten reduzieren.

In einer aktuellen Studie erwies sich die Behandlung der Rhodokokkose mit Gamithromycin $(6 \mathrm{mg} / \mathrm{kg} \mathrm{KGW}$, i.m., einmal wöchentlich, Zactran ${ }^{\circledR}$ ) als genauso effektiv wie die mit dem Goldstandard. Die intramuskuläre Injektion von Zactran ${ }^{\circledR}$ in die lange Sitzbeinmuskulatur des Fohlens hatte jedoch erheb- liche Nebenwirkungen wie Kolik und Lahmheit zur Folge. Ziel der vorliegenden Studie war es, zu ermitteln ob die intravenöse Injektion von Gamithromycin zur Behandlung der Rhodokokkose des Fohlens weniger unerwünschte Arzneimittelwirkungen aufweist und dabei aber genauso effektiv ist wie die intramuskuläre Injektion.

Bei der Untersuchung handelte es sich um eine retrospektive Betrachtung, die während der Saison 2013 auf einem norddeutschen Warmblut-Gestüt mit endemischer Rhodokokkose durchgeführt wurde. Auf diesem Betrieb wird ein Früherkennungsprogramm der Pneumonie bei allen Fohlen von Geburt an bis zum Absetzen vollzogen. Dieses umfasst sowohl eine regelmäßige klinische Untersuchung, als auch eine Bestimmung der Blutleukozytenzahl und eine ultrasonographische Untersuchung der Lunge. So können die abszedierenden Bronchopneumonien, die Rhodococcus equi auslöst, in einem frühen Stadium erkannt und schnell behandelt werden.

Fohlen mit ultrasonographischen Nachweisen von Lungenabszessen (Abszessscore $3-23 \mathrm{~cm}, \mathrm{n}=60$ ) bekamen 4 Wochen lang Gamithromycin in einer Dosierung von $6 \mathrm{mg} / \mathrm{kg} \mathrm{KGW}$ (Zactran ${ }^{\circledR}$, Merial, Lyon, Frankreich) einmal wöchentlich in zwei verschiedenen Verabreichungsformen. Die Tiere der Gruppe $1(n=40)$ bekamen Zactran ${ }^{\circledR}$ als Monotherapie in die lange Sitzbeinmuskulatur injiziert, den Tieren der Gruppe $2(n=20)$ wurde es als intravenöse Injektion in die Vena jugularis verabreicht (Tab.1). Die Tiere der Gruppe 2 bekamen eine Kombinationstherapie mit Rifampicin, welches in einer Dosierung von $10 \mathrm{mg} / \mathrm{kg} \mathrm{KGW}$ einmal täglich per os verabreicht wurde. Die Injektionen wurden wöchentlich wechselnd links und rechts durchgeführt. Jedes Fohlen wurde am Tag der Injektion mehrfach kontrolliert und an den darauf folgenden Tagen einmal täglich begutachtet um unerwünschte Arzneimittelwirkungen wie Schwellungen der Injektionsstelle und Thrombosenbildung, Kolik oder Lahmheit dokumentieren zu können. Fohlen, die sich deutlich verschlechterten, wurden aus der Studie entfernt.

Bei der Anzahl der unter der jeweiligen Therapie genesenen Fohlen gab es keine signifikanten Unterschiede. Die Anzahl der Fohlen, die unter der Behandlung mit Gamithromycin intramuskulär gesund wurden, betrug 38 (95\%), bei denen, die das Gamithromycin als intravenöse Applikation bekommen haben, betrug die Anzahl der genesenen Fohlen 16 (80\%) (Abb. 1).

Bei den unerwünschten Arzneimittelwirkungen gab es deutliche Unterschiede. So zeigten 23 von 40 Fohlen (58\%) in der Gruppe, die Gamithromycin in die lange Sitzbeinmuskulatur appliziert bekommen haben, erhebliche Nebenwirkungen. 18 Fohlen (45\%) zeigten deutliche Koliksymptome, 14 (35\%) wiesen eine teilweise hochgradige Lahmheit auf. Bei den Fohlen der Gruppe, die das Gamithromycin als i.v.-Applikation bekommen haben, wurden keinerlei unerwünschte Arzneimittelwirkungen beobachtet (Tab. 2, Abb. 3 und 4).

Als Fazit dieser Studie lässt sich abschließend sagen, dass Gamithromycin zur Therapie der Rhodokokkose sehr gut geeignet ist. Vom bisher gängigen Applikationsweg der Injektion in die lange Sitzbeinmuskulatur sollte jedoch aufgrund erheblicher Nebenwirkungen abgesehen und eine intravenöse Verabreichung in die Vena jugularis bevorzugt werden. 